\title{
Financial Distress Prediction of Lippo Group Companies Using Altman and Zmijewski Models
}

\author{
Putri Renalita Sutra Tanjung*, Dewi Anggraini \\ Accounting Study Program, Faculty Economics and Business, Universitas Mercu Buana Bambang Subiyanto, Erwin Indriyanto
}

DOI: $10.36348 /$ sjef.2020.v04i01.001

| Received: 27.12.2019 | Accepted: 04.01.2020 | Published: 11.01.2020

*Corresponding author: Putri Renalita Sutra Tanjung

\section{Abstract}

Financial distress Are the stages of a company's financial condition decline. Companies that experience financial distress in the long term tend to go bankrupt. Many parties will be harmed if a company goes bankrupt; for this reason, a bankruptcy prediction model is needed that can provide early warning for the company. This research was conducted to determine whether there are differences in financial distress prediction analysis using the Altman model, and the Lippo Group's Zmijewski Model, and to find out the most accurate bankruptcy prediction models. The analytical method used in this study is Logit Regression. The test results conclude that there are differences in predicting financial difficulties based on the Altman model, the Zmijewski Model.

Keywords: Financial distress, Altman Model, Zmijewski Model, Model, Logit Regression.

Copyright @ 2020: This is an open-access article distributed under the terms of the Creative Commons Attribution license which permits unrestricted use, distribution, and reproduction in any medium for non-commercial use (NonCommercial, or CC-BY-NC) provided the original author and source are credited.

\section{INTRODUCTION}

Every company is founded in the hope that it will make a profit so that it can survive or develop in the long run and does not experience liquidation. This assumption does not always happen well as expected. Often companies that have been operating for a certain period are forced to disperse or be liquidated due to financial difficulties that lead to bankruptcy. Companies that want to survive and get ahead need to develop new strategies. In an economy like this, not one market is forever safe from competition, both local and global. Changes in economic conditions often affect financial performance, small, medium, and large companies. If management is unable to manage correctly, then the shadow of a decline in business performance and even the danger of company bankruptcy will be faced by the company. A company will undoubtedly avoid conditions that can lead to bankruptcy. The liquidation of the company will cause various losses both for shareholders, employees, and the national economy. Bankruptcy is the worst financial distress.

Bankruptcy is a threat that looms over companies. Even established and old companies did not escape the danger of bankruptcy. Kodak is a major player in the film, camera, and printing industry for more than 125 years. Poor management and lack of innovation cause them to lose competitiveness. Kodak already has the technology to make digital cameras, but deliberately it was not launched yet for fear of killing the photo film roll business. However, consumers say differently and want the camera all digital so that Kodak finally launches a digital camera product too late. So that in 2012, Kodak was forced to apply for bankruptcy protection even though it was finally able to recover after paying USD 3.4 billion in debt.

In Indonesia, one of the businesses of a large company in the Lippo Group has also experienced bankruptcy. When the monetary crisis, almost all banks in Indonesia swayed, Bank Lippo was no exception. Lippo Bank owners are forced to release the majority of their shares in Lippo Bank to the Indonesian Government, related to the recapitulation of troubled bank assets. The greatness of the name of PT Bank Lippo Tbk finally disappeared from the Indonesian banking realm, after its shareholders merged with PT Bank Niaga Tbk in 2008. All of Bank Lippo shares were exchanged into Bank Niaga shares at a ratio of 2.822 Bank Niaga shares per 1 share of Bank Lippo.

PT Natrindo Telepon Seluler was initially part of the Lippo Group. Natrindo is the first GSM 1,800 $\mathrm{MHz}$ cellular telecommunications operator company in Indonesia with an initial focus on operating in the East Java region with the trademark Lippo Telecom. At the end of February 2008, Lippo Telecom and Natrindo merged into AXIS. In 2011 based on approval from the 
Ministry of Law and Human Rights, the name of the legal entity AXIS Company was changed from PT Natrindo Telepon Seluler to PT AXIS Telekom Indonesia.

Financial difficulties at PT AXIS Telekom Indonesia have occurred since early 2013. The company's shareholders no longer disburse funds so that Axis is experiencing financial aspects difficulties, including paying Frequency BHP. If there is no rescue from the company's management, the Axis may not be able to pay Frequency of Use Rights (BHP) fees to the government. If the company does not pay BHP to the government, it means that the country is threatened not to get revenue. Also, 17 million Axis customers will be threatened by not being able to enjoy Axis services. Thus, in 2014 PT XL Axiata Tbk. Acquired PT AXIS Telekom Indonesia. The decision to make mergers and acquisitions of Axis by XL by the management is considered an appropriate step to overcome the financial difficulties of the company's operations, also indirectly saving customers at the company.

In the third quarter of 2018, shares in the compact Lippo Group were in the red zone. Four Lippo Group shares, such as PT Lippo Cikarang Tbk (LPCK), PT Lippo Karawaci Tbk (LPKR), PT Matahari Putra Prima Tbk (MPPA), and PT Matahari Department Store Tbk (LPPF), experienced impairment. The decline in the value of shares in several companies in the Lippo Group was also caused by the news of the Corruption Eradication Commission (KPK) who suspected that there had been a bribery transaction to state administrators related to licensing of the Meikarta project which was worked on by a Lippo Group property development company. This case is also one of the reasons for the erosion of the capitalization of Lippo companies on the stock market and increases the risk of bankruptcy of its business.

Referring to the analysis of the Altman Z-score calculation, some Lippo Group companies have a high probability of collapse. The global rating agency also immediately issued a warning over the impact of bribery cases that befall Lippo Group companies. Rating agencies that gave their statements regarding the state of Lippo Group companies included Moody's Investor Service and Standard \& Poor's (S\&P).

Moody's Investor Service considers that the alleged bribery case is a negative sentiment for the performance of the Lippo Group issuers, especially Lippo Karawaci. Investor and consumer confidence will be eroded so that property sales in the project are threatened to slow down. This rating agency has downgraded Lippo Karawaci's credit rating from B2 to B3. This is the lowest credit level, high speculation (highly speculative grade) with a high credit risk profile.
Standard \& Poor's (S\&P) Global Ratings also assessed that this alleged bribery case raised questions about the company's internal governance. Lippo Karawaci is considered to have a thin liquidity buffer. This rating agency believes that the alleged bribery case will significantly affect the progress and cash flow of the Lippo Group property company project, and is predicted to lead to further pressure on company liquidity. In general, deteriorating financial conditions and significant debt burdens have caused Lippo Group companies to experience short-term and medium-term liquidity problems, which in turn threaten business continuity.

The events mentioned above can be ascertained; the cause is financial distress/financial distress. If this is handled late, it will cause bankruptcy/liquidation. Therefore it is essential to make early predictions about the possibility of financial distress so that the handling of problems can be done immediately.

Analysis of the symptoms of bankruptcy must be done to anticipate bankruptcy in the future. The ability to predict companies experiencing liquidity difficulties is beneficial for potential investors and creditors. If the company goes bankrupt, the creditor will lose revenue from principal and interest payments; the investor will lose his equity and the expected dividends. Moreover, if a company goes bankrupt, it will face the possibility of payment related to legal aspects. Many studies have tried to examine the causes or factors that influence the occurrence of financial distress using financial ratio indicators.

Predictions about financial distress have been carried out by experts. Anggraini and Mulya [1] mentioned that many studies have tried to examine the causes or factors that influence the occurrence of financial distress using financial ratio indicators. The Altman Model [2] is a model that is widely used to predict the likelihood of financial distress. In addition to the Altman Model, various other models have been developed, for example, the Springate Model, Zmijewski, the Grover Model, the Ohlson Model, the Beaver Model, and the Shumway Model.

The financial difficulty model needs to be developed because by knowing the company's financial difficulties early on, it is expected that actions can be taken to anticipate conditions that lead to bankruptcy. Financial difficulties occur before bankruptcy [3]. Terms of business problems can be identified earlier by using a particular model. This model can help potential investors and creditors to invest their capital so that they are not trapped in these financial difficulties. The model was developed by Jeffrey S Grover (Grover) in 1968, Springate in 1981, Zmijewski in 1983 [4]. 
Jeffrey S Grover developed the Grover model in 1968. The Grover model was created by designing and re-evaluating the Altman Z-Score model. The Grover model categorizes companies in bankruptcy if a score of less than or equal to $-0.02(\mathrm{Z}-0.02)$ is obtained. The next model is the Zmijewski Model. The prediction model produced by Zmijewski [5] is the result of 20 years of research that was reviewed [6]. Zmijewski uses the financial ratio of return on assets (ROA), leverage, and liquidity to get a more appropriate pattern [5]. This financial ratio was chosen not based on theory but derived from previous experience and research [5].

The next model that can be used to predict financial distress is the Springate Model. This method is a development of the Altman method using multiple discriminant analysis (MDA) [7]. Initially, this method used 19 popular financial ratios but, after retesting, Springate finally chose four ratios used in determining the criteria for companies included in the category of good companies or potentially bankrupt companies [6].

Furthermore, Zmijewski [8] uses a different theory, namely that profitability, volatility, and the condition of corporate leverage are the essential variables in predicting financial distress. This theory can be likened to the theory of liquidity, profitability, and wealth. The methodology used by Zmijewski is almost the same as that of Ohlson [6], which uses a lot of variables (multivariate) logit types. Based on research conducted by Andrianti [9], which states the Zmijewski Model is influential in predicting the company's financial distress. By Barbara Gunawan's study [9] that the Zmijewski model affects predicting financial distress and the Zmijewski model has a higher level of accuracy than the Altman model. Research with similar topics on financial difficulties has also been carried out, such as research from Citrawati and Gede [10] by comparing the Altman, Springate, and Zmijewski models at PT. Fast Food, Indonesia, Tbk. The results showed that the company's performance, in general, is in a healthy state or has no potential to go bankrupt. This is shown from the effects of testing using the three methods, namely the Altman, Springate, Zmijewski method.

The next research was conducted by Lukman and Ahmar [11] by comparing which bankruptcy prediction model is the strongest, namely between the Fullmer H-Score and Springate models of mining companies listed on the Indonesia Stock Exchange from 2011-2015. The results showed that the results of calculations using the Fullmer H-Score model of most mining companies in 2011-2014 indicated that the company went bankrupt $26.35 \%$ and $73.65 \%$ of the company was predicted as a healthy company and based on calculations using the Springate model from 20112014 resulted in $45.27 \%$ of companies mining is predicted as a healthy company, and $54.73 \%$ is predicted as a bankrupt company.
Based on the above background prediction of financial difficulties is very important to do, especially for investors who will invest in a company. Research on financial problems has been widely carried out in Indonesia. Still, research on financial difficulties by comparing several prediction models, including Ohlson's model and also taking five years as research material is minimal. Therefore this study seeks to determine the prediction of financial difficulties using the Altman model and the Zmijewski model.

\section{Formulation of the problem}

Based on the background that has been described, the wording of the problem in this study is:

- What is the condition of the Lippo Group Company, based on the prediction of the Altman model of financial distress analysis?

- What is the status of the Lippo Group Company, based on the prediction of the Zmijewski financial distress analysis model?

- Is there a difference between the Altman model and the Zmijewski model in predicting financial distress?

\section{LITERATURE REVIEW Signaling Theory}

Signaling Theory underpins this research; signal theory is used to explain that financial statements are used to give positive signals (good news) and negative signals (bad news) to the wearer. Tuvaratragool [12] researched the regulation of financial ratio comparisons in giving signs of financial distress by using multi-measuring techniques (IMM) consisting of emerging markets, score models, comparative ratio analysis, and trend analysis and logit models as benchmarking measures, results This research shows that financial statement information can be used as a media to find out the signal of a company's failure.

Information from company management that is written in the company's financial statements that gives a signal to analyze company performance and can show and provide a failure or success in management performance. As stated by Sunyoto [13], financial statements are a process of analysis and assessment that helps in answering questions as a means to an end. Financial statements are significant for every company, both companies that have gone public or not, because it can be used to determine the performance and financial condition of the company so that it can predict the potential for bankruptcy in the future.

\section{Altman's Z-Score Analysis Method}

According to Prihadi [14], the Z score from Altman is a method of calculating bankruptcy rates that are very well known from the past. Afternoon $\mathrm{Z}$ is the most suitable model used in Indonesia Anjum [15] examines the Altman Z Score bankruptcy prediction model. Edward Altman first introduced the $\mathrm{Z}$ score 
bankruptcy prediction model in 1968. The initial model from Dr. Altman was as follows:

$$
\mathrm{Z}=0.012 \mathrm{X}_{1}+0.014 \mathrm{X}_{2}+0.033 \mathrm{X}_{3}+0.006 \mathrm{X}_{4}+0.999 \mathrm{X}_{5}
$$

where:

$\mathrm{X}_{1}=$ Working capital/total assets

$\mathrm{X}_{2}=$ Retained earnings/total assets

$\mathrm{X}_{3}=$ Earnings before interest and taxes/total assets

$\mathrm{X}_{4}=$ Market value of equity/book value of total debt

$\mathrm{X}_{5}=$ Sales/total assets

Z Score calculation results indicate the company's condition as follows:

Z-score <1.81: most likely will go bankrupt

Z- Scores> 2.67: not bankrupt

Z-scores between 1.81 - 2.67: gray areas

In 1993, Altman continued his research and revised his model that eliminated $\mathrm{X} 5$ variables to eliminate industry effects in terms of company size related to assets or sales could be eliminated $[3,15]$.

$$
\mathrm{Z}=6.56\left(\mathrm{X}_{1}\right)+3.26\left(\mathrm{X}_{2}\right)+6.72\left(\mathrm{X}_{3}\right)+1.05\left(\mathrm{X}_{4}\right)
$$

Z-score $<1.10$ : most likely will go bankrupt

Z- Scores $>2.60$ : not bankrupt

Z-scores antara 1.10 - 2.60: gray areas

\section{Zmijewski Model (X-Score)}

The expansion of studies in bankruptcy predictions was carried out by Zmijewski [16] by adding the validity of financial ratios as a means of detecting corporate economic failures. Zmijewski conducted a study by reviewing the study of bankruptcy in the field of the results of previous research for twenty years. Several financial ratios were selected from the last research financial ratios. They sampled as many as 75 companies that went bankrupt, as well as 3573 healthy companies during 1972 to 1978, F-test indicators to group ratios, Rate of Return, liquidity, leverage, turnover, fixed payment coverage, trends, firm size, and stock return volatility, indicate a significant difference between healthy and unhealthy companies. The following is a model formulated by Zmijewski

$$
\mathrm{X} \text {-score }=-4,3-4,5 \mathrm{X}_{1}+5,7 \mathrm{X}_{2}-0,004 \mathrm{X}_{3}
$$

Description:

$X_{1}=$ EAT $/$ Total Assets $x 100 \%$ (Return On Asset)

$X_{2}=$ Total Debt / Total Asset x 100\% (Debt Ratio or Leverage)

$X_{3}=$ Current Asset / Current Liabilities (Current Ratio or Likuidity)

The Zmijewski model company classification is based on a cut of the point value of 0 (zero). If the XScore is below the cut-off point, the company is in a healthy condition. However, the X-Score is above the cut-off point; the company is in financial distress.

\section{Past Research}

Jones [17] A Cash Flow-Based Model of Corporate Bankruptcy in Australia develops a cash flow model by using net operating variables cash flow to total assets, quality of earnings (operating cash flow to EBIT), cash flow cover, and cash position to total assets. This study also shows that the Altman Z Score fails to predict financial distress in sample companies, and the Case-based model is much better than Altman. Case-based models can predict that financial pain will occur in the sample companies at least six months before the condition occurs in the company.

The results of Fawzi et al. [4] study of 104 companies in Malaysia in 2009-2012 using logit regression proved that the 5 (five) cash flow ratios were significant financial distress predictors, and the prediction accuracy reached $82.1 \%$.

Alostaz's research [18] on companies listed on the Palestinian stock exchange proves that the cashflow industry sector that is significant in predicting bankruptcy includes cash flow coverage of interest ratio, operating cash-flow margin ratio, and free cash flow on current liabilities ratio. By using logistic regression, the prediction accuracy reaches $80 \%$.

Hidayat [19]. Analysis in Predicting Bankruptcy Using Multiple Discriminant Analysis and Logit in the Pharmaceutical Industry Listed on the Indonesia Stock Exchange Period 2009-2014 Of the ten testing methods there are six of them experiencing differences in predicting bankruptcy namely Altman with Springate, Altman with Zmijewski, Altman with Olhson, Springate with Zmijewski, and Springate with Olhson.

The research of Dewi Anggraini and Hadri Mulya [1] used Binary logistic regression analysis method, which found the influence of financial distress prediction on several financial ratios such as Working Capital to Total Assets; Current Ratio; Book value of equity to Total Liabilities; Total Debt to Total Assets; EBIT to Current Liabilities; and Institutional Ownership.

Fardinal and Gandhy research [20] states that liquidity ratios and solvency ratios have a substantial negative relationship to financial distress, while profitability ratios have a robust positive correlation.

Veronita [21] Comparative Analysis of the Altman, Springate, Ohlson, Fulmer, CA-Score and Zmijewski Models in Predicting Financial Distress (empirical studies on Food and Beverages Companies Listed on the Indonesia Stock Exchange in the 20102012 Period) There are differences between the Ohlson, Altman Model, Springate, and Zmijewski. Ohlson's model has the highest level of conformity compared to the Altman, Springate, and Zmijewski models. The 
Springate model has the lowest compliance.

Putera et al. [3] Comparison of Financial Distress Predictions Using the Altman, Springate, and Ohlson Models The results of hypothesis testing with the Kruskall-Wallis test concluded that there were no differences in financial distress predictions with the Altman, Springate and Ohlson models.

Permana et al. [22]. Financial Distress Prediction in Manufacturing Companies on the
Indonesia Stock Exchange There is differences in health status in testing the Grover, Springate, and Zmijewski models. The Springate model is the best prediction model compared to the Grover and Springate models because it has more components than the other two models.

\section{Framework}

Based on the periodization chosen in this study and the previous description, the theoretical framework of this research is described as follows:

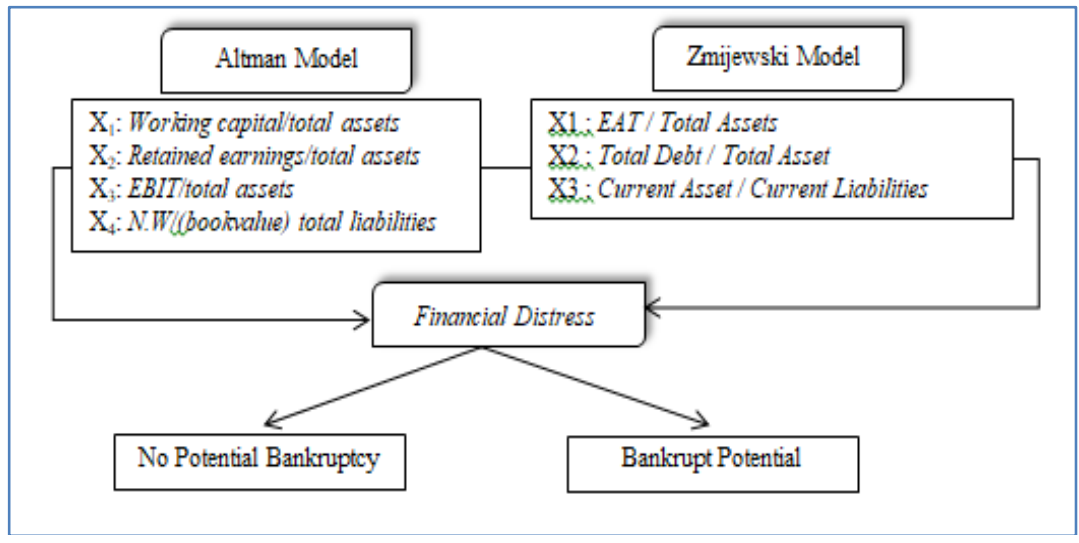

\section{Research Hypothesis}

With reference to the formulation of the problem, literature review as well as the framework of thought described earlier, the hypotheses proposed in this study are:

H1: Altman's model can predict financial distress.

$\mathrm{H} 2$ : Zmijewski's model can predict financial distress.

H3: There is a difference between the Altman model and the Zmijewski model in predicting financial distress.

\section{RESEARCH METHODS \\ Research and Operational Variables}

\section{Financial Distress}

In this research in calculating Financial

Distress using the Altman Z Score bankruptcy

prediction model, as

follows: $\mathrm{Z}=6.56\left(\mathrm{X}_{1}\right)+3.26\left(\mathrm{X}_{2}\right)+6.72\left(\mathrm{X}_{3}\right)+1.05\left(\mathrm{X}_{4}\right)$

Where:

$$
\begin{aligned}
& \mathrm{X}_{1}=\text { Working capital/total assets } \\
& \mathrm{X}_{2}=\text { Retained earnings/total assets } \\
& \mathrm{X}_{3}=\text { Earnings before interest and taxes/total } \\
& \text { assets } \\
& \mathrm{X}_{4}=\text { N.W./(bookvalue) total liabilities }
\end{aligned}
$$

\section{Zmijewski Model (X-Score)}

Zmijewski conducted a study by reviewing the study of bankruptcy in the field of the results of previous research for twenty years. The following is a model formulated by Zmijewski:

Where:
$\mathrm{X}_{1}=$ EAT $/$ Total Assets $x 100 \%$ (Return On Asset)

$\mathrm{X}_{2}=$ Total Debt / Total Asset x 100\% (Debt Ratio or Leverage)

$\mathrm{X}_{3}=$ Current Asset / Current Liabilities (Current Ratio or Likuiditas)

\section{Population and Research Samples}

The population used in this study is Lippo Group companies listed on the Indonesia Stock Exchange in 2013-2017. The Lippo Group Company was chosen as a sample because, based on the phenomenon that generally occurs; most of the Lippo Group companies currently have unfavorable financial conditions. Deteriorating economic conditions and significant debt burdens have caused Lippo Group companies to suffer from short and medium-term liquidity problems, which in turn have threatened business continuity.

\section{DATA ANALYSIS METHOD}

Data analysis was performed with Regression Analysis (Logistic Regression). The analytical method used in this study is a logistic regression analysis. The reason for choosing this method is that the data used in this study are non-metric on the dependent variable. In contrast, the independent variable is a mixture of continuous variables (metric data) and categorical (nonmetric data). Due to the mix of scales on these independent variables, the assumption of the multivariate normal distribution cannot be fulfilled. That causes the change of function to be logistical and does not require the assumption of data normality on the independent variable. Logit analysis is used to analyze quantitative data that reflects two choices or 
commonly called binary logistic regression [23]. Logistic regression aims to test whether the probability of the occurrence of the dependent variable can be predicted with the independent variable [16]. Logistic regression analysis was carried out with the help of the SPSS program.

\section{RESULTS AND DISCUSSION \\ Descriptive Altman Model}

The following is a descriptive result of the Altman model for the Lippo Group company for the period of 2013 - 2017:

Table-1: Descriptive Altman Model

\begin{tabular}{|l|r|r|r|r|r|}
\hline & \multicolumn{1}{|l|}{$\mathbf{N}$} & \multicolumn{1}{c|}{ Minimum } & \multicolumn{1}{c|}{ Maximum } & \multicolumn{1}{l|}{ Mean } & \multicolumn{1}{l|}{$\begin{array}{l}\text { Std. } \\
\text { Deviation }\end{array}$} \\
\hline WCTA & 45 & .03 & .69 & .4212 & .16935 \\
\hline RETA & 45 & .09 & .77 & .4501 & .20956 \\
\hline EBITTA & 45 & -.03 & .48 & .1713 & .12881 \\
\hline MVETL & 45 & .00 & 46.90 & 15.5636 & 14.70690 \\
\hline SALESTA & 45 & .78 & 1.76 & 1.1877 & .23351 \\
\hline SCORE & 45 & 1.73 & 30.37 & 12.2267 & 9.23682 \\
\hline $\begin{array}{l}\text { Valid N } \\
\text { (listwise) }\end{array}$ & 45 & & & & \\
\hline
\end{tabular}

\section{Descriptive Model Zmijewski} 2013 - 2017:

The following are the descriptive results of the Zmijewski model in the Lippo Group Company for the period

Table-2: Descriptive Model Zmijewski

\begin{tabular}{|l|r|r|r|r|r|}
\hline & \multicolumn{1}{|l|}{$\mathbf{N}$} & \multicolumn{1}{c|}{ Minimum } & \multicolumn{1}{c|}{ Maximum } & \multicolumn{1}{l|}{ Mean } & \multicolumn{1}{l}{$\begin{array}{l}\text { Std. } \\
\text { Deviation }\end{array}$} \\
\hline EATTA & 45 & -.042 & .363 & .12739 & .104602 \\
\hline TLTA & 45 & .069 & .656 & .30751 & .149447 \\
\hline CACL & 45 & 1.042 & 10.254 & 3.54186 & 2.121872 \\
\hline SCORE & 45 & -4.914 & -.429 & -3.13464 & 1.214422 \\
\hline $\begin{array}{l}\text { Valid N } \\
\text { (listwise) }\end{array}$ & 45 & & & & \\
\hline
\end{tabular}

\section{Financial Distress Analysis Results}

Altman Z-Score Model

The following is the result of the analysis of financial distress predictions of Lippo Group companies listed on the Indonesia Stock Exchange in 2013 - 2017 using the Altman Z-Score model where the cut-off if the value of $\mathrm{Z}<1.81$ then the company is predicted to experience financial distress, if the value of $1,81<\mathrm{Z}$ $<2.99$, the company is prone to bankruptcy and if $\mathrm{Z}\rangle$ 2.99 the condition of the company is healthy or not bankrupt.

Table 3 Calculation Results of the Altman Model

\begin{tabular}{|c|c|c|c|c|c|c|c|c|}
\hline Code & Year & $\mathbf{1 , 2}$ X1 & $\mathbf{1 , 4 . X 2}$ & $\mathbf{3 , 3 . X 3}$ & $\mathbf{0 , 6 . X 4}$ & $\mathbf{1 , 0 . X 5}$ & $\mathbf{Z - S c o r e}$ & Note \\
\hline \multirow{4}{*}{ LPPS } & 2013 & 0.69965 & 0.65512 & 0.46331 & 6.86117 & 0.92574 & 9.60499 & HEALTHY \\
\cline { 2 - 9 } & 2014 & 0.71251 & 0.69146 & 0.25353 & 3.85162 & 0.88929 & 6.39841 & HEALTHY \\
\cline { 2 - 9 } & 2015 & 0.65179 & 0.65391 & 0.30389 & 2.16114 & 0.94901 & 4.71973 & HEALTHY \\
\cline { 2 - 9 } & 2016 & 0.54425 & 0.69102 & 0.43882 & 2.60094 & 0.94775 & 5.22278 & HEALTHY \\
\cline { 2 - 9 } & 2017 & 0.53681 & 0.68811 & 0.44238 & 2.50165 & 0.96024 & 5.12918 & HEALTHY \\
\hline \multirow{5}{*}{ LPKR } & 2013 & 0.16455 & 0.22194 & -0.08216 & 0.39726 & 1.03072 & 1.73232 & PRONE \\
\cline { 2 - 9 } & 2014 & 0.17506 & 0.22698 & 0.12237 & 0.99710 & 1.10536 & 2.62687 & PRONE \\
\cline { 2 - 9 } & 2015 & 0.17325 & 0.18953 & 0.11819 & 0.33199 & 1.05750 & 1.87046 & PRONE \\
\cline { 2 - 9 } & 2016 & 0.12904 & 0.18711 & 0.07986 & 10.79911 & 1.21212 & 12.40724 & HEALTHY \\
\cline { 2 - 9 } & 2017 & 0.02957 & 0.12382 & -0.00924 & 10.93352 & 1.06631 & 12.14398 & HEALTHY \\
\hline \multirow{5}{*}{ LPCK } & 2013 & 0.51676 & 0.58317 & 0.39217 & 1.92998 & 1.75897 & 5.18105 & HEALTHY \\
\cline { 2 - 9 } & 2014 & 0.44535 & 0.54468 & 0.38312 & 3.77949 & 1.41518 & 6.56782 & HEALTHY \\
\cline { 2 - 9 } & 2015 & 0.35226 & 0.59402 & 0.37569 & 2.10984 & 1.41501 & 4.84681 & HEALTHY \\
\cline { 2 - 8 } & 2016 & 0.31493 & 0.50766 & 0.31681 & 3.91435 & 1.25993 & 6.31368 & HEALTHY \\
\hline
\end{tabular}




\begin{tabular}{|c|c|c|c|c|c|c|c|c|}
\hline & 017 & 0.25444 & 44687 & 0.28997 & 2.55347 & .00514 & 4.54989 & HEALTHY \\
\hline \multirow{5}{*}{ LPPF } & 013 & \begin{tabular}{|l|l|}
0.51487 \\
\end{tabular} & 290 & 0.74431 & 12.37896 & 41369 & 15.99474 & \\
\hline & 2014 & & & & & & & \\
\hline & 2015 & 21 & & & 23 & & 15 & \\
\hline & 2016 & 57181 & 04963 & .64828 & 5.42614 & 27244 & 18.96 & $\mathrm{HE}$ \\
\hline & 2017 & 56450 & 7744 & .62737 & 7.46060 & 460 & 52 & \\
\hline \multirow{5}{*}{ PPA } & 13 & 77 & 02 & & 21 & & 93 & \\
\hline & 2014 & 2 & & & 20 & & 08 & \\
\hline & 2015 & 0J & 3 & 24 & 0.8 & & 14. & \\
\hline & 2016 & 5 & 32 & 94 & 00 & & 19.7 & $\mathrm{HE}$ \\
\hline & 2017 & ( & & 0. & 0 & & 01 & \\
\hline \multirow{5}{*}{ LIN } & 3 & & & & & & & \\
\hline & 2014 & $D_{0}+2 \rightarrow$ & & 19 & 36 & & & \\
\hline & 2015 & 7 & & $2(2$ & 0.6 & & 2.8 & \\
\hline & 2016 & 7 & & 20 & 4 & & & $\mathrm{HY}$ \\
\hline & 2017 & 4 & & & 33 & & 3.6 & $\mathrm{HE}$ \\
\hline & & & & & 55 & & 09 & \\
\hline & 2014 & 0 & & 0.52 & 8.1 & & 30.3 & $\mathrm{HE}$ \\
\hline & 2015 & 8 & & 0. & 56 & & 27. & $\mathrm{HE}$ \\
\hline & 2016 & & & & 83 & & 22.7 & $\mathrm{HE}$ \\
\hline & 2017 & & & 0. & 61 & & 21.0 & $\mathrm{HE}$ \\
\hline \multirow{5}{*}{ MLPT } & 3 & & & & 55 & & 74 & $\mathrm{HY}$ \\
\hline & 2014 & 0 & & 0.3 & 0.00 & & $3.1^{1}$ & $\mathrm{HE}$ \\
\hline & 2015 & & & & & & & \\
\hline & 2016 & 0.49774 & & & & & 3.06 & THY \\
\hline & 2017 & 49175 & & & 07 & 556 & 2.85374 & NE \\
\hline \multirow{5}{*}{ SILO } & & 7 & & 99 & 01 & 246 & 29.3 & $\mathrm{HE}$ \\
\hline & 2014 & & & & 21.3 & & 25.6 & $\mathrm{HE}$ \\
\hline & 2015 & 064 & 010 & & 18.88329 & 922 & 22.8 & $\mathrm{HY}$ \\
\hline & 2016 & 67628 & & 26 & 20.4 & 223 & 24.54755 & $\mathrm{HE}$ \\
\hline & 2017 & $.083 / 5$ & 6416 & 1.59119 & 20.18651 & 1.17269 & 24.39834 & $\mathrm{HE}$ \\
\hline
\end{tabular}

Based on the table above, there are no companies that are predicted to go bankrupt, but there are some companies that are declared bankrupt, such as PT. Lippo Cikarang Tbk. in 2013 until 2015 had a cut off value $\mathrm{Z}$ score prone to bankruptcy, that is because in 2013 LPCK had a negative value of X3 (Earnings Before Interest Tax to Total Assets), the company suffered losses resulting in its Z Score being at the point of bankruptcy. Following Altman's model theory, which states that this ratio is the most significant contributor to the model, the ratio measures the company's ability to generate profits from the assets used. In 2014, the Z score increased even though it was still at the point of bankruptcy, but in 2015 the $\mathrm{Z}$ score dropped again due to the entire ratio of the Altman model experiencing a decrease in value.

Companies that are also categorized as bankrupt are PT. Link Net Tbk. in 2013-2015 this is because the value of debt is more significant than its market value which can be seen in the amount of the Market value equity/book value of debt ratio where this ratio measures the company's ability to provide guarantees to each debt through its capital. Neither the company PT. Multipolar Technology Tbk in 2015 and 2017 , although in general, the value of the ratio is good because the debt value is higher than the market value, the company has a Z Score in the category of bankruptcy in that year.

\section{Zmijewski Model}

The following are the results of the analysis of financial distress predictions of Lippo Group companies listed on the Indonesia Stock Exchange in 2013-2017 using the Zmijewski model. The Zmijewski model company classification is based on a cut-off point of 0 (zero). If the X-Score is below the cut-off point, the company is in a healthy condition. However, the XScore is above the cutoff point; the company is in financial distress. 
Putri Renalita Sutra Tanjung \& Dewi Anggraini., Saudi J Econ Fin, Jan 2020; 4(1): 1-11

Table-4: Calculation Results of the Zmijewski Model

\begin{tabular}{|c|c|c|c|c|c|c|}
\hline Code & Year & X7 = EAT/TA & X8 = TD/TA & X9 = CA/CL & XSCORE & Note \\
\hline \multirow{5}{*}{ LPPS } & 2013 & 0.1057065 & 0.181061748 & 4.15201492 & -3.760235342 & HEALTHY \\
\hline & 2014 & 0.065738919 & 0.236686787 & 4.914002963 & -3.266366462 & HEALTHY \\
\hline & 2015 & 0.078395798 & 0.29264497 & 3.522904705 & -2.99879638 & HEALTHY \\
\hline & 2016 & 0.099312277 & 0.295021619 & 2.854937379 & -3.076701767 & HEALTHY \\
\hline & 2017 & 0.098879068 & 0.319696817 & 2.662125751 & -2.933332453 & HEALTHY \\
\hline \multirow{5}{*}{ LPKR } & 2013 & -0.041786179 & 0.551925169 & 1.265221012 & -0.971049615 & HEALTHY \\
\hline & 2014 & 0.000932176 & 0.529749469 & 1.303583884 & -1.289837157 & HEALTHY \\
\hline & 2015 & 0.004281126 & 0.613545291 & 1.26150718 & -0.827102938 & HEALTHY \\
\hline & 2016 & -0.012569905 & 0.583277942 & 1.210768172 & -0.923594228 & HEALTHY \\
\hline & 2017 & -0.03025411 & 0.655913083 & 1.042195267 & -0.429320715 & HEALTHY \\
\hline \multirow{5}{*}{ LPCK } & 2013 & 0.087236086 & 0.41211511 & 2.426696743 & -2.353213045 & HEALTHY \\
\hline & 2014 & 0.080708331 & 0.404330376 & 2.386994589 & -2.368052322 & HEALTHY \\
\hline & 2015 & 0.07364815 & 0.400051102 & 1.922822713 & -2.358816684 & HEALTHY \\
\hline & 2016 & 0.058882225 & 0.507560626 & 1.713667175 & -1.678729114 & HEALTHY \\
\hline & 2017 & 0.054412699 & 0.578008876 & 1.545506944 & -1.256388577 & HEALTHY \\
\hline \multirow{5}{*}{ LPPF } & 2013 & 0.174077475 & 0.250897381 & 2.839259175 & -3.664590605 & HEALTHY \\
\hline & 2014 & 0.170643301 & 0.215058194 & 3.403636661 & -3.855677696 & HEALTHY \\
\hline & 2015 & 0.15023595 & 0.20137612 & 3.697774102 & -3.843008987 & HEALTHY \\
\hline & 2016 & 0.154399285 & 0.181410771 & 4.131144325 & -3.977279965 & HEALTHY \\
\hline & 2017 & 0.147641795 & 0.163828142 & 4.509400669 & -4.048605269 & HEALTHY \\
\hline \multirow{5}{*}{ MPPA } & 2013 & 0.250822428 & 0.27857091 & 3.979465175 & -3.856764601 & HEALTHY \\
\hline & 2014 & 0.256164448 & 0.234596925 & 4.585873163 & -4.133881037 & HEALTHY \\
\hline & 2015 & 0.222155644 & 0.261987641 & 3.652181842 & -3.820979573 & HEALTHY \\
\hline & 2016 & 0.206796116 & 0.21676954 & 4.216600894 & -4.011862548 & HEALTHY \\
\hline & 2017 & 0.170810125 & 0.273397065 & 3.080965345 & -3.522606156 & HEALTHY \\
\hline \multirow{5}{*}{ LINK } & 2013 & 0.035390167 & 0.46397194 & 1.536792284 & -1.820762863 & HEALTHY \\
\hline & 2014 & 0.015420956 & 0.437308333 & 1.626793817 & -1.883243977 & HEALTHY \\
\hline & 2015 & 0.019299596 & 0.367170451 & 1.991182986 & -2.301941343 & HEALTHY \\
\hline & 2016 & 0.030802789 & 0.368448313 & 2.190841062 & -2.34722053 & HEALTHY \\
\hline & 2017 & 0.044665483 & 0.317790681 & 3.522764913 & -2.703678849 & HEALTHY \\
\hline \multirow{5}{*}{ MLPL } & 2013 & 0.137353669 & 0.115576672 & 7.288473797 & -4.288458375 & HEALTHY \\
\hline & 2014 & 0.148039215 & 0.069175218 & 10.25424542 & -4.612894704 & HEALTHY \\
\hline & 2015 & 0.156458381 & 0.070740039 & 9.276534826 & -4.637950634 & HEALTHY \\
\hline & 2016 & 0.160839051 & 0.076893802 & 8.318226496 & -4.618753962 & HEALTHY \\
\hline & 2017 & 0.169020118 & 0.08306414 & 7.81221254 & -4.618373787 & HEALTHY \\
\hline \multirow{5}{*}{ MLPT } & 2013 & 0.11787485 & 0.291950466 & 2.961941868 & -3.178166937 & HEALTHY \\
\hline & 2014 & 0.104427293 & 0.272290495 & 3.002185648 & -3.229875742 & HEALTHY \\
\hline & 2015 & 0.084207075 & 0.309892136 & 2.537551431 & -2.922696867 & HEALTHY \\
\hline & 2016 & 0.082828651 & 0.296172375 & 2.65214035 & -2.995154949 & HEALTHY \\
\hline & 2017 & 0.074962617 & 0.31646583 & 2.521377159 & -2.843562051 & HEALTHY \\
\hline \multirow{5}{*}{ SILO } & 2013 & 0.354998486 & 0.176015725 & 4.967925486 & -4.914075257 & HEALTHY \\
\hline & 2014 & 0.337013372 & 0.196959271 & 4.372921052 & -4.711384011 & HEALTHY \\
\hline & 2015 & 0.323703347 & 0.236998949 & 3.573541369 & -4.420065218 & HEALTHY \\
\hline & 2016 & 0.344707269 & 0.259589565 & 3.369173805 & -4.384998887 & HEALTHY \\
\hline & 2017 & 0.363481844 & 0.27200028 & 3.325436925 & -4.398568452 & HEALTHY \\
\hline
\end{tabular}

Based on the table above, there are no companies that are predicted to go bankrupt in the 2013-2017 periods. The Zmijewski model only uses 3 (three) ratios in determining bankruptcy conditions, namely profitability ratios, leverage ratios and liquidity ratios. Where two of these ratios are a measure of a company's ability to meet its obligations or debts both long term and short term. In accordance with the theory of Brigham \& Daves [24] which says that financial distress starts when a company cannot meet the payment schedule or when the cash flow projection indicates that the company will soon be unable to meet its obligations. In the Zmijewski model, the Lippo Group Company listed on the Indonesia Stock Exchange in 2013-2017 has a pretty good leverage and liquidity ratio so that the company's condition does not experience financial distress. 
Normality Test Results

Altman Model Normality Test Results

Table-5: Test the Altman Model Normality

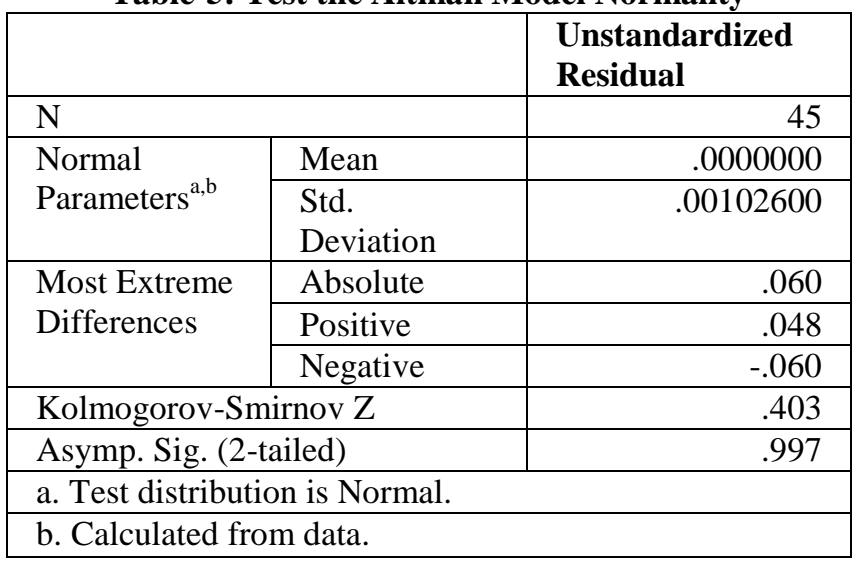

Based on the table in the table above the Kolmogorov-Smirnov $\mathrm{Z}$ value is 0.403 and the probability value of 0.997 shows that the probability value is greater than the significant value of 0.05 , so it can be concluded that the data are normally distributed.

\section{Zmijewski Model Normality Test Results}

Table-6: Normality Test for the Zmijewski Model

\begin{tabular}{|l|l|r|}
\hline \multicolumn{2}{|c|}{ One-Sample Kolmogorov-Smirnov Test } \\
\hline \multicolumn{2}{|c|}{} & \multicolumn{1}{|c|}{$\begin{array}{l}\text { Unstandardized } \\
\text { Residual }\end{array}$} \\
\hline $\mathrm{N}$ & Mean & .0000000 \\
\hline Normal \\
Parameters
\end{tabular}

Based on the table in the table above, the Kolmogorov-Smirnov $\mathrm{Z}$ value is 0.690 , and the probability value is 0.729 ; this shows that the probability value is higher than the significant amount of 0.05 , so it can be concluded that the data are typically distributed.

\section{Research Hypothesis Test Results}

This test is used to test whether paired samples have a significantly different mean. Paired sample (matched sample) is a sample with the same subject but experienced different treatments or measurements; this test is carried out to find out whether there are differences between the Altman model and Zmijewski, Decision making is based on Asymp values. Sig. (2tailed). If the probability (in this case, the Asymp.Sig. (2-tailed) value> 0.05, then there is no significant difference between the two sample groups. But if the probability is $<0.05$, then there is a substantial difference between the two sample groups. Below are the results of the SPSS output on the paired-sample ttest hypothesis testing.

Table-7: Paired Sample T-Test

\begin{tabular}{|c|c|c|c|c|c|c|c|}
\hline \multicolumn{8}{|c|}{ Paired Samples Test } \\
\hline & & \multicolumn{3}{|c|}{ Paired Differences } & \multirow[t]{3}{*}{$\mathrm{t}$} & \multirow[t]{3}{*}{$\mathrm{df}$} & \multirow{3}{*}{$\begin{array}{l}\text { Sig. (2- } \\
\text { tailed) }\end{array}$} \\
\hline & & \multirow[t]{2}{*}{$\begin{array}{l}\text { Std. } \\
\text { Deviation }\end{array}$} & \multicolumn{2}{|c|}{$\begin{array}{l}\text { 95\% Confidence Interval } \\
\text { of the Difference }\end{array}$} & & & \\
\hline & & & Lower & Upper & & & \\
\hline Pair 1 & Altman - Zmijewski & 10.20942 & 12.29407 & 18.42857 & 10.093 & 44 & .000 \\
\hline
\end{tabular}

Based on the output results in the table above, there is a Sig. (2-tailed) of 0,000 in pair one between the Altman and Zmijewski models. These results indicate a probability $<0.05$, which means that there are significant differences between the two sample groups.
DISCUSSION OF RESEARCH RESULTS

Based on the results of the paired sample t-test in the previous table shows the results of the significance of $0.00<0.05$ so it can be concluded that there are differences in the results of the analysis of financial distress potential between the Altman Z-Score model with Zmijewski with a $95 \%$ confidence level. 
These results are in line with previous research by Dimas [25], which states that there are differences between the Altman Z-Score and Zmijewski models. The results of this study are also in line with Wulandari [10], which says that there are differences between the Altman Z-Score and Zmijewski models.

\section{CONCLUSIONS AND SUGGESTIONS Conclusions}

This study aims to determine whether or not there are differences in predictions between the Altman Z-Score and Zmijewski and identify the most accurate model in predicting the financial distress conditions of pharmaceutical companies listed on the Indonesia Stock Exchange in the 2013-2017 periods. Based on the results of the research it has been concluded that there are differences in the results of the analysis of the potential for financial distress between the Altman ZScore model and Zmijewski on pharmaceutical companies listed on the Indonesia Stock Exchange in the 2013-2017 period. In the Altman Z-Score model, there are no samples that are predicted to experience financial distress. Still, eight samples are predicted to be prone to financial distress, whereas, in the Zmijewski model, there are no samples that are predicted to experience financial distress or prone to financial distress.

\section{SUGGESTION}

The advice given by the author is as follows:

1. For Company Management. Based on the two methods of bankruptcy prediction, results are not entirely accurate, but the results of this analysis can provide signals of financial difficulties in a company.

2. For investors and creditors. Before investing in shares or providing capital loans to companies, investors and creditors need to know the financial condition of the company; first, this is important because to understand how far the company's ability to provide profits and return debt loans. The author suggests that investors and creditors to reconsider investing and giving debts to companies that are in the bankrupt category or are even more likely to experience financial difficulties using the Altman and Zmijewski method.

3. For further researchers in the next researcher, it is recommended to increase the number of samples of the study period, the mechanical characteristics used as samples, and other prediction methods to get better research results.

\section{REFERENCES}

1. Anggraini, D., \& Mulya, H. (2017). Financial Distress Prediction in Indonesia Companies: Finding An Alternative Model.RJOAS,1(61). January; 29-38.

2. Altman, E. I. (1968). Financial Ratio Discriminant, Analisis and The Prediction of Corporate Bankruptcy. Journal of Financial, 22(4)
3. Rahayu., \& Putri. (2016). Analisis penggunaan metode springate (S-SCORE) Sebagai prediktor kebangkrutan (Studi pada Perusahaa Textile yang Terdaftar di Bursa Efek Indonesia pada Tahun 2011-2013. Jurnal Ekonomi Universitas Muhammadiyah Surakarta, 1(1): 55-68

4. Darsono., \& Ashari. (2005). Pedoman Praktis Memahami Laporan Keuangan. Yogyakarta: Andi Fawzi, Noor Salfizan .,Kamaludin, Amrizah, Sanusi Mohd, Zuraidah, 2015, Monitoring Distressed Companies through Cash Flow Analysis, 7th international conference on financial criminology, 2015 13-14 April 2015,Wadham College, Oxford, United Kingdom

5. Zmijewski, M.E. (1984). Methodological Issues Relate to the Estimation of Financial of Financial Distress Prediction Models. Journal of Accounting Research. Vol 22: 59-71

6. Wulandary, V., \& Nur, E. (2014). Analisis Perbandingan Model Altman, Springate, Ohlson, Fulmer, CA-Score dan Zmijewski Dalam Memprediksi Kesulitan keuangan (studi empiris pada Perusahaan Food and Beverages yang Terdaftar di Bursa Efek Indonesia Periode 20102012),1(2): 1-18

7. Springate, Gord, L.V. (1978). Predicting the Possibility of Failure in a Canadian Firm. (Unpublished MBA Research Project). Simoon Fraser University

8. Zmijewski, M. E. (1983). Predicting corporate bankruptcy: An empirical comparison of the extant financial distress models. Document de travail. State University of New York at Buffalo.

9. Andrianti, P. T., Gunawan, P. I., \& Hoesin, F. (2016). Profil Epilepsi Anak dan Keberhasilan Pengobatannya di RSUD Dr. Soetomo Tahun 2013. Sari Pediatri, 18(1), 34-39.

10. Citrawati, E., \& M. Gede. (2014). Analisis Kesulitan keuangan Altman, Springate, dan Zmijewski pada PT. Fast Food Indonesia, Tbk. EJurnal Fakutas Universitas Udayana, Vol 6 (3): 379-389

11. Lukman, M., \& N. Ahmar. (2015). Model Prediksi Kebangkrutan Fullmer H-Score dan Springate: Mana yang lebih Kuat?. Seminar Nasional Cendikiawan 2015 STIE Perbanas: 12-29

12. Yami, H, R, N. (2013). Prediksi Kebangkrutan dengan Mengunakan Metode Altman ZScore, Springate, dan Zmijewski pada Perusahaan Properti \& Real Estate yang terdaftar di BEI tahun 20112013. Jurnal Fakultas Ekonomi dan Bisnis Universitas Niswantara Vol 1 No 1: Hal 1-12

13. Sunyoto, D. (2013). Perilaku konsumen. CAPS (Center of Academy Publishing Service), Yogyakarta.

14. Prihadi, S. (2010). Mengenal Beberapa Teori Lokasi.

15. Anjum, N. A., Ahmad, I., Mohmood, I., Pacheco, M., Duarte, A. C., Pereira, E., \& Prasad, M. N. V. (2012). Modulation of glutathione and its related 
enzymes in plants' responses to toxic metals and metalloids - a review. Environmental and Experimental Botany, 75, 307-324.

16. Imanzadeh, P.J.M., \& M. Sepehri. (2011). A Study of the Application of Springate and Zmijewski Bankruptcy Prediction Models in Firms Accepted in Tehran Stock Exchange. Australian Journal of Apllied Sciences, 25(3): 321-335

17. Jones, S., \& Hensher, D. A. (2004). Predicting firm financial distress: A mixed logit model, The Accounting Review, 79(4): 1011-1038.

18. Alostaz, A.O. (2015). Predicting Corporate Failure Using Cash Flow Statement Based Measures "An Empirical Study on the Listed Companies in the Palestine Exchange" Islamic University of Gaza

19. Hidayat, K. N., Glasbergen, P., \& Offermans, A. (2015). Sustainability certification and palm oil smallholders' livelihood: a comparison between scheme smallholders and independent smallholders in Indonesia. International Food and Agribusiness Management Review, 18(1030-2016-83041), 2548.

20. Gandhy, F. (2019). Analysis of Financial Ratio to Predict Financial Distress Conditions (Empirical
Study on Manufacturing Companies listed on the Indonesia Stock Exchange for 2014-2017). IJBMI, PP 27-34.

21. Husein, P, M., \& T.G. Pambekti. (2014). Precision of the models of Altman, Springate, Zmijewski, and Grover for predicting the financial distress. Journal of Economics, Business, and Accountancy Ventura, 17(3): 405-416

22. Permana, R. K., Ahmar, N., \& Djadang, S. (2017). Prediksi Financial Distress pada Perusahaan Manufaktur di Bursa Efek Indonesia. Esensi: Jurnal Bisnis dan Manajemen, 7(2), 149-166.

23. Jones, S. (2016). A cash flow based model of corporate bankruptcy in Australia. Journal of Applied Management Accounting Research, 14(1), 23.

24. Puspitasari, W. E. (2014). Penggunaan Model Zmijewski, Springate, Altman Z-Score, dan Grover dalam memprediksi kepailitan pada perusahaan transportasi yang terdaftar di BEI. Jurnal FEB Universitas Dian Nuswantoro, 4(5): 80- 94. S

25. Brigham, E. F., \& Daves, P. R. (2003). "Intermediate Financial Management with Thomson One. 